Vol. 5 (1996): 449-460.

\title{
Electrofusion of protoplasts of anther-derived dihaploid lines of commercial potato cultivars
}

\author{
Veli-Matti Rokka \\ Agricultural Research Centre of Finland, Institute of Crop and Soil Science, Plant Breeding Section, \\ FIN-31600 Jokioinen, Finland \\ Yong-Sheng Xu \\ Department of Plant Production, P.O. Box 27, FIN-00014 University of Helsinki, Finland
}

Pirjo Tanhuanpää

Agricultural Research Centre of Finland, Institute of Crop and Soil Science, FIN-31600 Jokioinen, Finland

Leena Pietilä

Boreal Plant Breeding, Myllytie 10, FIN-31600 Jokioinen, Finland

Eija Pehu

Department of Plant Production, P.O. Box 27, FIN-00014 University of Helsinki, Finland

\begin{abstract}
Somatic hybrids of anther-derived dihaploid ( $2 \mathrm{x}$ ) potato (Solanum tuberosum $\mathrm{L}$.) lines were produced by electrofusion of protoplasts. Using RAPD (randomly amplified polymorphic DNA) markers, six new combinations of dihaploid parental lines from cultivars Matilda, Nicola, Pito, Stina, Van Gogh and White Lady were identified. RAPD marker identification of the putative hybrids was mostly done using two distinct parental line specific primers. $43 \%$ of the 76 regenerated calli from the six combinations produced hybrid shoots. Most of the somatic hybrids were tetraploid (4x), but in four fusion combinations plants of hexaploid $(6 \mathrm{x})$, octoploid $(8 \mathrm{x})$ or mixoploid level were also identified by chromosome counts or flow cytometric nuclear DNA analysis. The mean nuclear DNA content (2C value) of the tetraploid and hexaploid somatic hybrids was lower than the expected DNA content (i.e. the $2 \mathrm{C}$ values of the original tetraploid cultivars or the sum of the $2 \mathrm{C}$ values of the dihaploid fusion parents). Some somatic hybrids having the expected nuclear DNA content were also found.
\end{abstract}

Key words: flow cytometry, ploidy level, RAPD, Solanum tuberosum, somatic hybridization

\section{Introduction}

Protoplast fusion has become an important method for crop improvement, and has been par- ticularly successful in species from the Solanaceae and Brassicaceae (Glimelius 1988). In potato breeding, protoplast technology has been applied extensively. Recent results have shown that especially intraspecific fusion of dihaploid potato 


\section{Rokka, V.-M. et al. Electrofusion of protoplasts of dihaploid lines of potato}

lines cannot be considered only as a sophisticated research method, but rather a technique which can now be applied successfully in potato breeding (Möllers and Wenzel 1992, Schweis and Munzert 1993, Möllers et al. 1994).

Cultivated potato, Solanum tuberosum L. ssp. tuberosum, is tetraploid $(2 \mathrm{n}=4 \mathrm{x}=48)$ and highly heterozygous, and breeding programmes based on crossing seldom produce progenies superior to the parental lines (Ross 1986). Therefore, reduction in ploidy level has been attempted, either through chromosome elimination effected by pollination with Solanum phureja Juz. et Buk. (Hougas and Peloquin 1957) or anther culture (Dunwell and Sunderland 1973). Resulting dihaploids $(2 n=2 x=24)$ expressing the desired phenotype can be screened and the tetraploid condition reconstituted by fusion of protoplasts of two different dihaploid lines (Wenzel et al. 1979). Dihaploid-dihaploid fusion programmes have been initiated by several research groups (e.g. Austin et al. 1985, Debnath and Wenzel 1987, Waara et al. 1989, Baird et al. 1992, Schweis and Munzert 1993), but only Waara et al. (1989, 1991, 1992) have published the use of antherderived dihaploids in their intraspecific somatic hybridization programme.

Somatic hybrids must be distinguished from unfused material or fusion products resulting from homokaryon fusions. Various selection methods have been developed. Hybrid fusion products can be selected using a micromanipulator (Waara et al. 1991), flow sorter (Puite et al. 1988), hybrid vigour (Debnath and Wenzel 1987), intermediate morphology (Gleddie et al. 1986), mutant lines (White and Vasil 1979) or with selectable markers (Masson et al. 1989). Identification of hybridity based on molecular (Pehu et al. 1989, 1990, Baird et al. 1992) and biochemical analysis (Waara et al. 1989, Cooper-Bland et al. 1994) has also been applied. It is essential that the identification for hybridity is simple and quick due to the high number of fusion products to be screened.

The genetic composition of the intraspecific somatic hybrids is expected to be balanced (the hybrids are euploid tetraploids), but aneuploidy and different ploidy levels are common among hybrid regenerants (Waara et al. 1992, Rasmussen and Rasmussen 1995). In this study, antherderived dihaploid potato lines derived from cvs. Matilda, Nicola, Pito, Stina, Van Gogh and White Lady were electrofused in various combinations. The somatic hybrids were characterized by chromosome counts and nuclear DNA content determination by flow cytometry. The objective of the study was to produce and characterize new intraspecific somatic hybrids for potato breeding purposes. The aim of the study was also to get more information on potato breeding at the diploid level in order to move anther cultures and protoplast fusions as part of the practical potato breeding.

\section{Material and methods}

\section{Plant material}

Dihaploid potato lines 'Nicola 2.dh.2.1.1.', 'Pito 35.dh.7.4.1.', 'Pito 30.dh.16.1.1.', 'Pito 12.dh.57.3.1.', 'Van Gogh 13.dh.11.3.1.', 'Van Gogh 7.dh.12.2.1.', 'Van Gogh 19.dh.37.1.1.' and 'White Lady 4.dh.2.3.2.' were produced by anther culture (Tiainen 1992, Rokka et al. 1996). Dihaploid lines 'Matilda 1.dh.536.6' and 'Stina 4.dh.161.15' were provided from The Swedish University of Agricultural Sciences. All of the genotypes were aseptically cultured in vitro on MS20 medium (Murashige and Skoog 1962) containing $20 \mathrm{~g} \mathrm{l}^{-1}$ sucrose, $100 \mathrm{mg} \mathrm{l}^{-1}$ caseinhydrolysate, $0.05 \mathrm{mg} \mathrm{l}^{-1} \mathrm{NAA}$ ( $\alpha$-naphthaleneacetic acid) and $2 \mathrm{mg} \mathrm{l}^{-1}$ STS (silver thiosulphate). The cultures were maintained in a photoperiod of $16 \mathrm{~h}$ per day $\left(63 \mu \mathrm{E} \mathrm{m} \mathrm{m}^{-2} \mathrm{~s}^{-1}\right)$ at a temperature of $24^{\circ} \mathrm{C}$.

\section{Protoplast isolation}

Leaf material of 4 to 6-week-old plants was cut into small sections and placed in $10-20 \mathrm{ml}$ of preplasmolysis solution $(0.5 \mathrm{M}$ mannitol $)$ for $1 \mathrm{~h}$. 
Vol. 5 (1996): 449-460.

The material was then transferred into $10 \mathrm{ml}$ of enzyme solution (Rokka et al. 1994).

After 16-18 h enzyme treatment in the dark at $24^{\circ} \mathrm{C}$, the protoplast suspension was filtered through a $48 \mu \mathrm{m}$ nylon sieve. The filtrate was centrifuged at $80 \mathrm{~g}$ for $5 \mathrm{~min}$. The protoplast pellet was resuspended in wash solution containing the major salts of CPW medium with mannitol (Jones et al. 1989). Viable protoplasts were separated from dead protoplasts by centrifugation at $120-160 \mathrm{~g}$ for $5 \mathrm{~min}$ on $30 \%(\mathrm{v} / \mathrm{v})$ Percoll (Pharmacia Fine Chem. AB). The layer of viable protoplasts on the surface of the Percoll solution was collected and washed with the wash solution followed by two further washes in the fusion solution ( $0.5 \mathrm{M}$ mannitol, $\left.0.2 \mathrm{mM} \mathrm{CaCl}_{2}\right)$.

\section{Electrofusion and culture of the protoplasts}

For the fusion experiments the protoplasts of the fusion parents were mixed in a 1:1 ratio. The protoplast mixture, adjusted to a density of $2 \mathrm{x}$ $10^{5} \mathrm{ml}^{-1}$ with the fusion solution, was transferred into a lamellar chamber. The protoplasts were aligned and fused according to Rokka et al. (1994). Following fusion, the protoplasts in mannitol solution $(500 \mu \mathrm{l})$ were pipetted into $3.5 \mathrm{~cm}$ diameter Petri dishes to which double strength V-KM culture medium (Bokelmann and Roest 1983) was added in a ratio of $1: 1$. The protoplasts were embedded adding $0.9 \%$ (w/v) lowgelling-temperature agarose (Type VII, Sigma) and cultured in the dark at $24^{\circ} \mathrm{C}$. After $10-14$ days the cultures were resuspended with 3-7 ml per plate normal strength V-KM medium and transferred to dim light. When colonies developed (after 3-5 weeks), the cultures were continued as described by Rokka et al. (1994), except that STS $\left(2 \mathrm{mg} \mathrm{l}^{-1}\right)$ was added to the media D and SP (Creissen and Karp 1985).

\section{Analysis of hybridity by RAPD patterns}

DNA extraction was carried out according to Rokka et al. (1994). The RAPD primers were synthesized either on an Applied Biosystems 372 DNA/RNA Synthesizer or purchased from Operon Technologies (Alameda, USA). Different 10or 11-mer primer sequences were used to establish polymorphisms between the dihaploid lines. Primers producing unique amplification products in both parental lines, or preferably, sequentially used primers producing genotype specific bands, were used in identification of somatic hybrids. The PCR (polymerase chain reaction) was carried out as described by Rokka et al. (1995).

\section{Chromosome counts and nuclear DNA content determination}

Chromosome numbers were counted from root tip cells of in vitro (MS20 $\left.+0.05 \mathrm{mg} \mathrm{l}^{-1} \mathrm{NAA}\right)$ cultured plants according to Tiainen (1992). Nuclear DNA content ( $2 \mathrm{C}$ values) was measured from the dihaploid parental lines, the tetraploid original cultivars and the somatic hybrids using flow cytometry as described by Rokka et al. (1995). 1000-4000 nuclei were analysed in each sample.

\section{Results}

\section{Protoplast isolation and culture}

The protoplast yields varied considerably between dihaploids, and in many cases one of the parental lines of the fusion combination had more burst and collapsed protoplasts than the other (data not shown). Embedding in $0.9 \%$ agarose decreased the burst of the protoplasts during the first days of culture. Compared to culturing of the protoplasts in liquid medium, more divisions and colonies occured in embedded medium. The resuspension of cultures by liquid V-KM medium after 11-14 days enhanced strongly the rate of divisions, and the dilutions also prevented browning of the growing colo- 
Rokka, V.-M. et al. Electrofusion of protoplasts of dihaploid lines of potato

Table 1. Nucleotide sequences of the RAPD primers, which were used in identification of hybridity.

\begin{tabular}{lccl}
\hline Fusion combination & Primer code* & Sequence (5' to 3') & Bands specific to \\
\hline Pito 35.dh.7.4.1. (+) Matilda 1.dh.536.6 & 107 & GAC TGC AGA C & Pito and Matilda \\
Pito 35.dh.7.4.1. (+) Stina 4.dh.161.15 & 102 & TGA TCG ACT CG & Pito and Stina \\
Pito 35.dh.7.4.1. (+) Van Gogh 7.dh.12.2.1. & OPB-08 & GTC CAC ACG G & Pito \\
& OPK-08 & GAA CAC TGG G & Van Gogh \\
& OPB-09 & TGG GGG ACT C & Pito \\
Pito 30.dh.16.1.1. (+) Van Gogh 13.dh.11.3.1. & OPK-08 & GGA CAC TGG G & Van Gogh \\
& OPB-09 & TGG GGG ACT C & Pito \\
Pito 12.dh.57.3.1. (+) Nicola 2.dh.2.1.1. & OPB-05 & TGC GCC CTT C & Nicola \\
& & & \\
Van Gogh 19.dh.37.1.1. (+) & OPK-02 & GTC TCC GCA A & Van Gogh \\
White Lady 4.dh.2.3.2. & OPB-10 & CTG CTG GGA C & White Lady \\
& & &
\end{tabular}

* primers assigned with numbers were synthesized on a DNA synthesizer, primers with the prefix OP were purchased from Operon Technologies

Table 2. Frequency of regeneration and hybridity of the dihaploid-dihaploid fusion products.

\begin{tabular}{lcccc}
\hline Fusion combination & $\begin{array}{c}\text { no. of calli } \\
\text { regenerated } \\
\text { into shoots }\end{array}$ & $\begin{array}{c}\text { no. of } \\
\text { hybrid } \\
\text { calli }\end{array}$ & $\begin{array}{c}\text { hybrid calli (\%) } \\
\text { from all } \\
\text { regenerated }\end{array}$ & $\begin{array}{c}\text { no. of } \\
\text { hybrid } \\
\text { shoots }\end{array}$ \\
\hline Pito 35.dh.7.4.1. (+) Matilda 1.dh.536.6 & 22 & 3 & $14 \%$ & 21 \\
Pito 35.dh.7.4.1. (+) Stina 4.dh.161.15 & 5 & 1 & $20 \%$ & 32 \\
Pito 35.dh.7.4.1. (+) Van Gogh 7.dh.12.2.1. & 4 & 4 & $100 \%$ & 7 \\
Pito 30.dh.16.1.1. (+) Van Gogh 13.dh.11.3.1. & 21 & 6 & $29 \%$ & 47 \\
Pito 12.dh.57.3.1. (+) Nicola 2.dh.2.1.1. & 12 & 11 & $92 \%$ & 30 \\
Van Gogh 19.dh.37.1.1. (+) White Lady 4.dh.2.3.2. & 12 & 8 & $67 \%$ & 78 \\
\hline TOTAL & 76 & 33 & $43 \%$ & 215
\end{tabular}

nies. The time required from protoplast isolation and fusion to shoot formation ranged from 5 to 8 months depending on the fusion combination.

\section{Identification of somatic hybrids using RAPDs}

Polymorphisms between parental dihaploids were tested with several primers. In the dihaploid combination 'Pito 35.dh.7.4.1. (+) Stina 4.dh.161.15' six primers were tested, three of which generated significantly different banding patterns. In the combination 'Pito 35.dh.7.4.1. (+) Matilda 1.dh.536.6' two primers out of 14 primers produced different patterns for the pa- rental lines. In these two combinations, a single primer allowed successful identification of hybridity (Table 1). The somatic hybrids contained the combined pattern of the parental lines, whereas unfused material and regenerants derived from homokaryon fusions had the pattern of only one of the parental dihaploid lines.

Two distinct parental-line-specific primers were used in the identification of the hybrids in the other four fusion combinations ('Pito 35.dh.7.4.1. (+) Van Gogh 7.dh.12.2.1.', 'Pito 30.dh.16.1.1. (+) Van Gogh 13.dh.11.3.1.', 'Pito 12.dh.57.3.1. (+) Nicola 2.dh.2.1.1.' and 'Van Gogh 19.dh.37.1.1. (+) White Lady 4.dh.2.3.2.') (Table 1). Thus, $90 \%$ (44/49) of the primers generated polymorphism specific to one of the parental lines. Using two such parental-line- spe- 
Fig. 1. Regenerants from fusion combination of dihaploid potato lines ('Pito 30.dh.16.1.1. (+) Van Gogh 13.dh.11.3.1.') identified by RAPDs. The amplification was made by primer B09 (OPB-09) (lanes 1-10) and primer K08 (OPK-08) (lanes 11-20). Primer B09 produced a 'Pito 30.dh.16.1.1.' specific band of $1600 \mathrm{bp}$ (lane 1), which was visible both in the mixed DNA of the dihaploids (lane 3) and in all protoplast fusion regenerants (lanes 410). Primer K08 amplified a 'Van Gogh 13.dh.11.3.1.' specific band of 1900 bp (lane 12 ), which was visible in the mixed DNA of the dihaploids (lane 13) and in two protoplast fusion regenerants: 1302 (lane 14) and 1903 (lane 20) i.e. those regenerants were somatic hybrids. A 100 bp DNA ladder (Gibco BRL) was used as a molecular weight marker. (Photo: Veli-Matti Rokka).
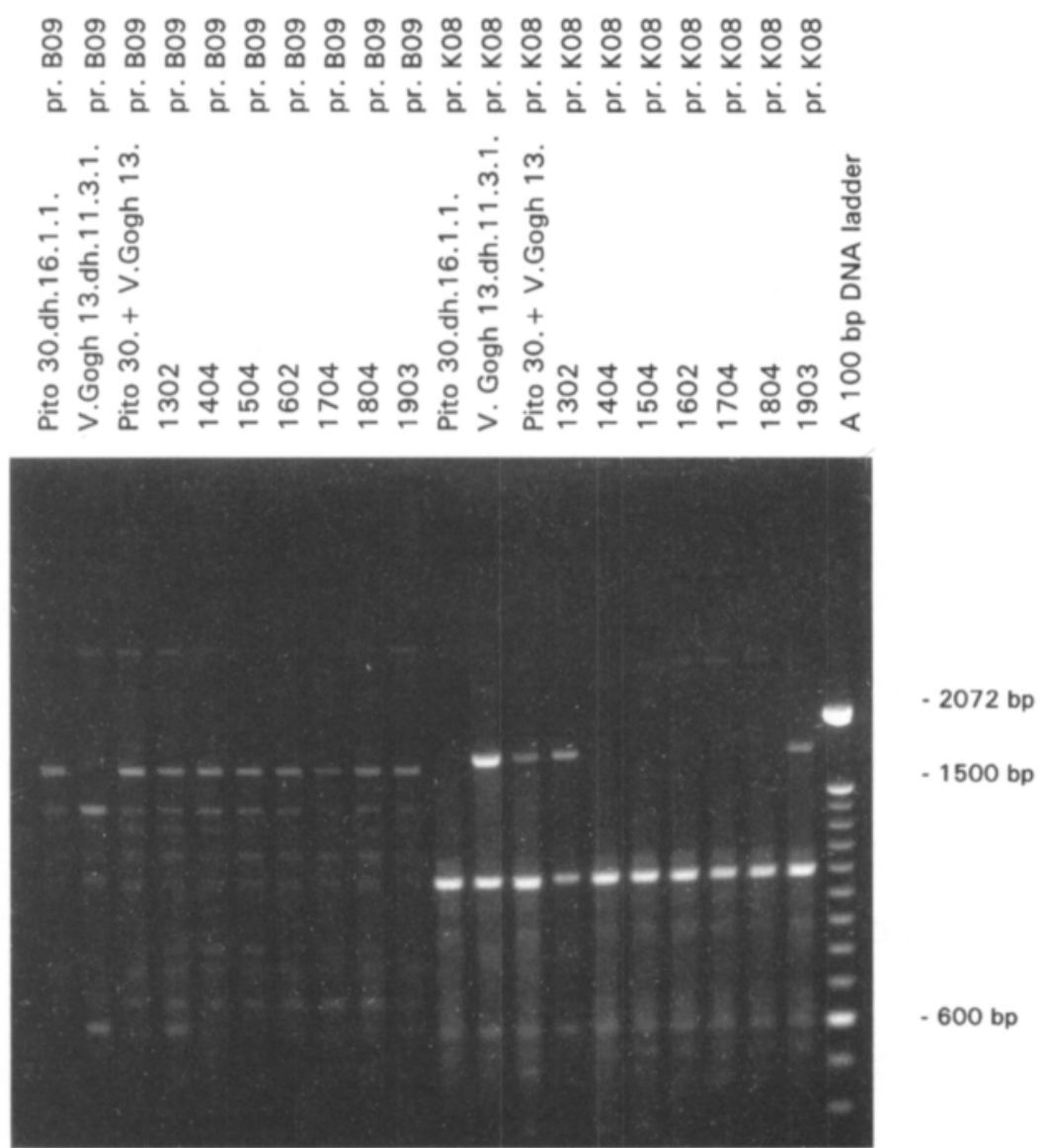

1. 2. 3. 4. 5. 6. 7. 8. 9. 10, 11, 12, 13, 14, 15, 16, 17, 18, 19, 20, 21. cific primers required twice as much resources, but were more reliable in the hybridity verification than the use of a single primer. An example of the identification of somatic hybrids is shown in Figure 1. The frequency of somatic hybrids was estimated for six different fusion combinations (Table 2). In total, 215 hybrid shoots were recovered from a total of 33 calli (Table 2).

\section{Chromosome counts and flow cytometric determination of nuclear DNA content}

Chromosomes of 24 shoots regenerated from one callus of a fusion combination 'Pito 35.dh.7.4.1.
(+) Stina 4.dh.161.15' were counted. All of the hybrids were tetraploid, chromosome numbers ranging from 45 to 50 . Ploidies of all of the somatic hybrids derived from seven different calli of the fusion combination 'Pito 35.dh.57.3.1. (+) Nicola 2.dh.2.1.1.' were also tetraploid. The other fusion combinations produced both tetraploid, hexaploid, octoploid and mixoploid hybrids (Table 3 ). The total number of dihaploid-dihaploid fusion calli, which produced somatic hybrid regenerants of different ploidy levels is shown in Table 4. Yet, the tetraploid level was the most common.

The mean DNA content (2C value) determined from leaf nuclei in dihaploid parental lines of the three fusion combinations (Table 5) was 
Rokka, V.-M. et al. Electrofusion of protoplasts of dihaploid lines of potato

Table 3. Ploidy level of the dihaploid-dihaploid somatic hybrids of potato derived from six fusion combinations. The ploidy levels were determined with chromosome counts and/or flow cytometric nuclear DNA analysis.

\begin{tabular}{|c|c|c|}
\hline Fusion combination & $\begin{array}{c}\text { callus } \\
\text { no. }\end{array}$ & $\begin{array}{c}\text { No. of regenerants/ } \\
\text { ploidy level }\end{array}$ \\
\hline \multirow[t]{3}{*}{ Pito 35.dh.7.4.1. (+) Matilda 1.dh.536.6 } & 01 & $5 / 6 x$ \\
\hline & 02 & $14 / 8 x$ \\
\hline & 10 & $2 / 4 x, 1 / 8 x$ \\
\hline Pito 35.dh.7.4.1. (+) Stina 4.dh.161.15 & 01 & $24 / 4 x$ \\
\hline \multirow[t]{3}{*}{ Pito 35.dh.7.4.1. (+) Van Gogh 7.dh.12.2.1. } & 01 & $2 / 8 x$ \\
\hline & 02 & $1 / 4 x, 1 / 6 x-8 x^{*}$ \\
\hline & 03 & $1 / 4 x-6 x^{*}, 2 / 8 x$ \\
\hline \multirow[t]{5}{*}{ Pito 30.dh.16.1.1. (+) Van Gogh 13.dh.11.3.1. } & 08 & $5 / 6 x$ \\
\hline & 10 & $4 / 6 x$ \\
\hline & 11 & $7 / 4 x$ \\
\hline & 12 & $6 / 4 x$ \\
\hline & 19 & $4 / 6 x$ \\
\hline \multirow[t]{7}{*}{ Pito 12.dh.57.3.1. (+) Nicola 2.dh.2.1.1. } & 01 & $2 / 4 x$ \\
\hline & 02 & $2 / 4 x$ \\
\hline & 03 & $1 / 4 \mathrm{x}$ \\
\hline & 04 & $2 / 4 x$ \\
\hline & 06 & $1 / 4 x$ \\
\hline & 11 & $1 / 4 x$ \\
\hline & 18 & $1 / 4 x$ \\
\hline \multirow[t]{7}{*}{ Van Gogh 19.dh.37.1.1. (+) White Lady 4.dh.2.3.2. } & 04 & $2 / 8 x$ \\
\hline & 06 & $7 / 4 x$ \\
\hline & 08 & $13 / 6 x$ \\
\hline & 09 & $9 / 4 x$ \\
\hline & 10 & $6 / 6 x$ \\
\hline & 12 & $5 / 6 x$ \\
\hline & 13 & $4 / 6 x$ \\
\hline
\end{tabular}

* mixoploid shoots at $6 x$ and $8 x(6 x-8 x)$ levels or $4 x$ and $6 x(4 x-6 x)$ levels

Table 4. Number of dihaploid-dihaploid fusion calli, which produced somatic hybrid regenerants of different ploidy levels.

\begin{tabular}{ccc}
\hline Ploidy & No. of calli & $(\%)$ \\
\hline $4 \mathrm{x}$ & 12 & 46.2 \\
$6 \mathrm{x}$ & 8 & 30.8 \\
$8 \mathrm{x}$ & 3 & 11.5 \\
$4 \mathrm{x} / 6 \mathrm{x} / 8 \mathrm{x}^{*}$ & 3 & 11.5 \\
\hline TOTAL & 26 & 100.0 \\
\hline
\end{tabular}

* shoots derived from the same callus, but having different ploidy levels between 1.65 and $1.73 \mathrm{pg}$. The mean $2 \mathrm{C}$ values of the original tetraploid cultivars were generally two times higher (3.32 pg in cv. Pito, $3.44 \mathrm{pg}$ in cv. White Lady, $3.47 \mathrm{pg}$ in cv. Nicola and 3.48 $\mathrm{pg}$ in cv. Van Gogh) compared to the corresponding dihaploid lines. The mean $2 \mathrm{C}$ values of all of the tetraploid somatic hybrids (3.18-3.29 pg) derived from three fusion combinations, were lower than the expected $2 \mathrm{C}$ values (i.e. the $2 \mathrm{C}$ values of the original tetraploid cultivars or the sum of the $2 \mathrm{C}$ values of the dihaploid parents) (Table 5). Also in hexaploid somatic hybrids the 
Vol. 5 (1996): 449-460.

Table 5. DNA content (2C values) in leaf nuclei of dihaploid parental lines and the corresponding somatic hybrids in three fusion combinations.

\begin{tabular}{|c|c|c|c|}
\hline \multirow[t]{2}{*}{ Plant } & \multirow[t]{2}{*}{ ploidy } & \multicolumn{2}{|c|}{$2 \mathrm{C}$ value $(\mathrm{pg})^{*}$} \\
\hline & & mean & s.d. \\
\hline \multicolumn{4}{|c|}{ Fusion combination 'Pito 12.dh.57.3.1. (+) Nicola 2.dh.2.1.1.' } \\
\hline Pito 12.dh.57.3.1. & $2 \mathrm{x}$ & 1.65 & 0,03 \\
\hline Nicola 2.dh.2.1.1. & $2 \mathrm{x}$ & 1.73 & 0,01 \\
\hline expected $2 \mathrm{C}$ values & $2 x+2 x$ & 3.38 & \\
\hline Pito & $4 x$ & 3.32 & 0,05 \\
\hline Nicola & $4 x$ & 3.47 & 0,05 \\
\hline somatic hybrids & $4 \mathrm{x}$ & 3.24 & 0,07 \\
\hline \multicolumn{4}{|c|}{ Fusion combination 'Pito 30.dh.16.1.1. (+) Van Gogh 13.dh.11.3.1.' } \\
\hline Pito 30.dh.16.1.1. & $2 \mathrm{x}$ & 1.66 & 0,05 \\
\hline Van Gogh 12.dh.11.3.1. & $2 x$ & 1.65 & 0,00 \\
\hline expected $2 \mathrm{C}$ values & $2 x+2 x$ & 3.31 & \\
\hline Pito & $4 x$ & 3.32 & 0,05 \\
\hline Van Gogh & $4 x$ & 3.48 & 0,03 \\
\hline somatic hybrids & $4 x$ & 3.18 & 0,13 \\
\hline expected $2 \mathrm{C}$ values & $2 x+2 x+2 x$ & 4.97 & \\
\hline somatic hybrids & $6 x$ & 4.67 & 0,26 \\
\hline \multicolumn{4}{|c|}{ Fusion combination 'Van Gogh 19.dh.37.1.1. (+) White Lady 4.dh.2.3.2.' } \\
\hline Van Gogh 19.dh.37.1.1. & $2 \mathrm{x}$ & 1.73 & 0,02 \\
\hline White Lady 4.dh.2.3.2. & $2 \mathrm{x}$ & 1.72 & 0,03 \\
\hline expected & $2 x+2 x$ & 3.45 & \\
\hline Van Gogh & $4 x$ & 3.48 & 0,03 \\
\hline White Lady & $4 x$ & 3.44 & 0,02 \\
\hline somatic hybrids & $4 x$ & 3.29 & 0,33 \\
\hline expected $2 \mathrm{C}$ values & $2 x+2 x+2 x$ & 5.18 & \\
\hline somatic hybrids & $6 x$ & 4.77 & 0,41 \\
\hline
\end{tabular}

* mean of three flow cytometric measurements and standard deviation

mean $2 \mathrm{C}$ values were lower $(4.56-4.77 \mathrm{pg})$ than the expected $2 \mathrm{C}$ values (4.97-5.18 pg) (Table 5). However, in each fusion combination there were a number of regenerants having the same or higher $2 \mathrm{C}$ values than the original cultivars. The hybrids having higher $2 \mathrm{C}$ values were probably hypertetraploids or hyperhexaploids. Examples of the flow cytometric DNA content determination of the potato material are shown in Figure 2.

\section{Discussion}

In this study, six new dihaploid potato line combinations were produced by electrofusion of protoplasts. The genetic material of the anther-derived dihaploid parents originated from Scandinavian (cvs. Matilda, Pito and Stina), Dutch (cv. Van Gogh) and Hungarian (cv. White Lady) potato cultivars. Furthermore, the results of this study demonstrate the applicability of RAPD analysis in identification of intraspecific somat- 
Rokka, V.-M. et al. Electrofusion of protoplasts of dihaploid lines of potato

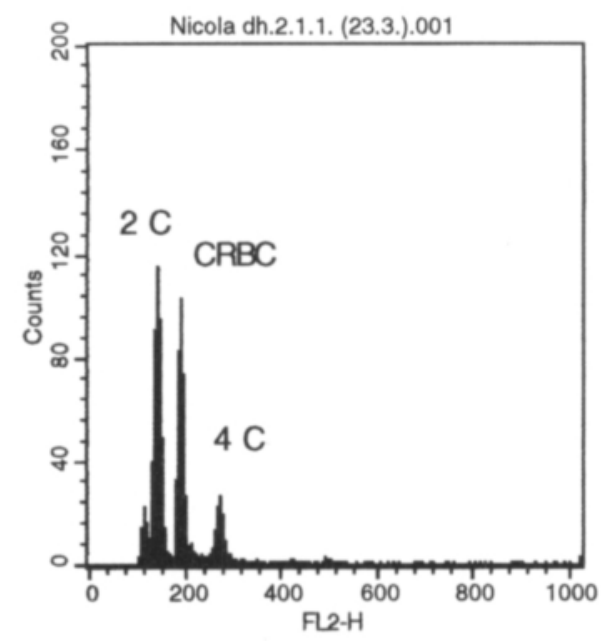

a.

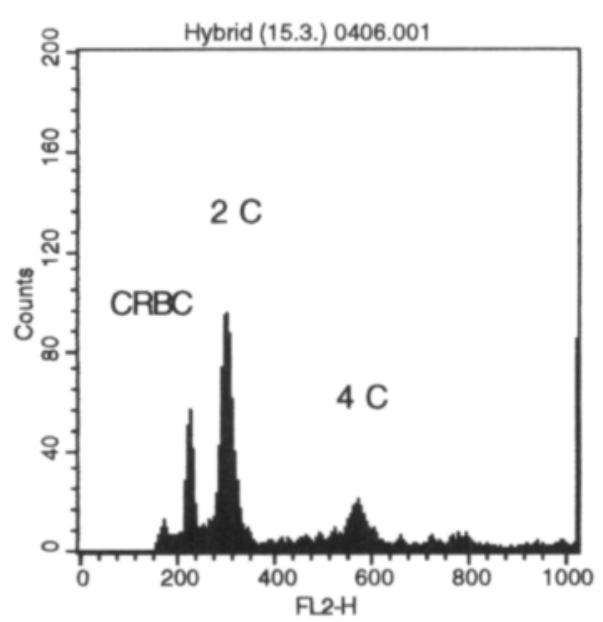

c.

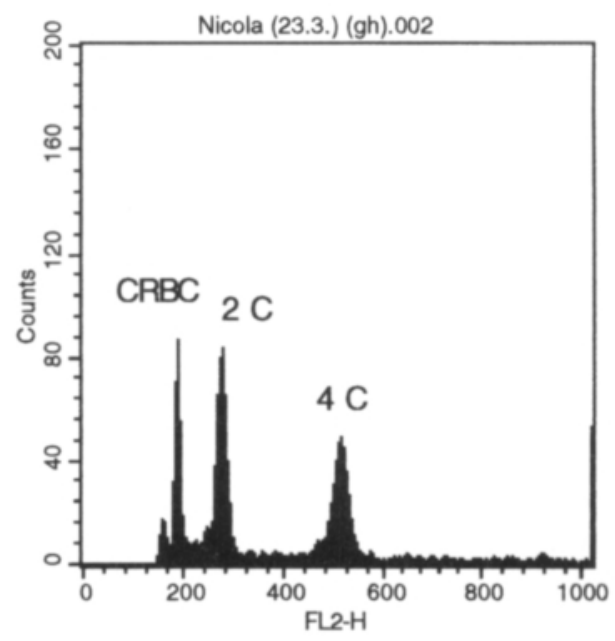

b.

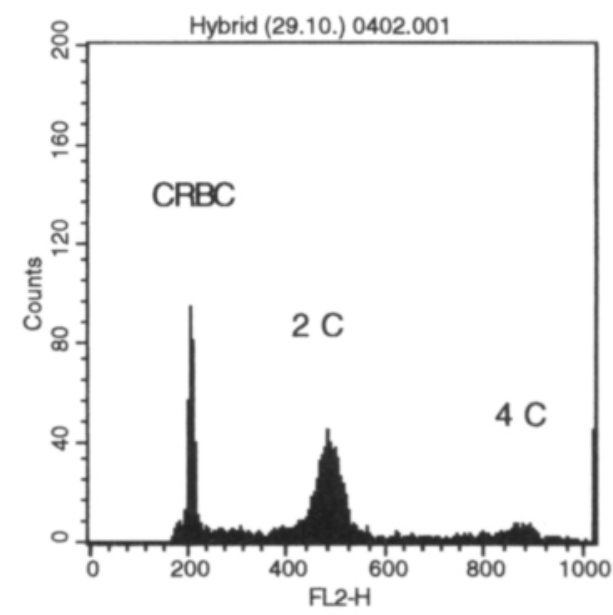

d.

Fig. 2. Flow cytometry of leaf nuclei of a dihaploid potato 'Nicola 2.dh.2.1.1.' (Fig. a.), a tetraploid cultivar Nicola (Fig. b.), a tetraploid somatic hybrid 0406 between two dihaploid lines ('Pito 12.dh.57.3.1. (+) Nicola 2.dh.2.1.1.') (Fig. c.) and a hexaploid somatic hybrid 0402 between two dihaploids ('Van Gogh 19.dh.37.1.1. (+) White Lady 4.dh.2.3.2.') (Fig. d.). The histograms were generated by propidium-iodide stained leaf nuclei and chicken red blood cell (CRBC) controls using linear scale of fluorescence intensity (FL2-H). CRBC were added as an internal standard to the plant nuclei samples. The signal threshold was adjusted to eliminate most debris from analysis. The nuclear DNA content ( $2 \mathrm{C}$ value) was calculated by direct comparison of the modal position of the plant peaks to the modal position of the CRBC peak (DNA content $=2.33 \mathrm{pg}$ ). $2 \mathrm{C}$ is defined as the DNA content of the plant in the G1 phase of the cell cycle and $4 \mathrm{C}$ in $\mathrm{G} 2$ phase (C is the DNA content of a haploid cell). 


\section{AGRICULTURAL AND FOOD SCIENCE IN FINLAND}

Vol. 5 (1996): 449-460.

ic hybrids of potato, and flow cytometric nuclear DNA content analysis of the hybrids.

In previous research works, anther-derived dihaploids have seldom been used in intraspecific somatic hybridizations, because anther culture of $S$. tuberosum has been considered ineffective in the production of dihaploids. Our recent results, however, in androgenesis of agronomically important potato cultivars, have been promising (Rokka et al. 1996). The advantage of producing dihaploid lines through anther culture is that the anther-derived dihaploids do not contain any other genetic material than that of the anther culture source plant. Dihaploids produced by $S$. phureja pollinations may contain $S$. phureja DNA or variable chromosome numbers (Clulow et al. 1993). The application of electrofusion rather than chemical fusion increases also the final number of somatic hybrids (Tempelaar and Jones 1985). The embedding of fused protoplasts with agarose followed by dilution steps, enhanced first divisions of the cultured protoplasts. However, the whole culturing process of $S$. tuberosum protoplasts is still quite limiting, if a wide range of genotypes is to be included in a protoplast fusion programme.

Generally, the methods for identification and selection of hybrid plants have also been a bottle-neck in protoplast fusion. However, RAPDs offer an opportunity to confirm the hybridity during very early stages of cultures. Because simple DNA extraction method can be applied for RAPD analysis, it is possible to screen a large number of regenerated plants in a short time (Rokka et al. 1994). Compared with isozyme (Waara et al. 1989, Möllers and Wenzel 1992) and RFLP (restriction fragment length polymorphism) analysis (Pehu et al. 1989), the RAPD method is fast. Isozyme analysis and RAPDs have given similar results in verification of somatic hybridity (Rasmussen and Rasmussen 1995). In the case that the hybrids should contain the combination of the bands of the both parental lines (using a single primer), competition for amplification sites in the target DNA may result in the absence of line-specific bands in the true somatic hybrids. Thus, the reproduc- ibility of parental-specific bands would be more reliable using two primers, when each produce parental-specific bands rather than a single primer. However, one parental band may also be missing as noted by Rasmussen and Rasmussen (1995), who suggested this to be due to the lack of specific chromosomes carrying the corresponding primer sequence in the hybrids. In the present work, all the strongly diagnostic bands gave consistent results in the identification of hybridity. Primers can also amplify sequences of mitochondrial and chloroplast origin (Lorenz et al. 1994). Complete chloroplast segregation is normal in intraspecific somatic hybrids (Lössl et al. 1994), but mitochondria can produce rearrangements (Xu et al. 1993, Lössl et al. 1994). In rare cases nuclear hybrids may be identified as non-hybrids, if the primer amplifies chloroplast DNA of the other parent.

In this study, two fusion combinations produced only tetraploid somatic hybrids, but in four combinations either tetraploid, hexaploid, octoploid or mixoploid hybrids were regenerated. In some cases the same callus regenerated into shoots which differed in ploidy levels from each other, which may be due to genetic rearrangements during the callus stage and shoot regeneration or the calli were derived from aggregated protoplasts or cell colonies (Waara et al. 1992). Rasmussen and Rasmussen (1995) noticed that in one fusion combination only few of the hybrids were tetraploid. Other than the expected tetraploid levels can also be explained by fusion of more than two individual protoplasts. Chimeras are also possible to occur after compaction of protoplasts or because of the grafted groups of cells as described by Binding et al. (1988). The mean nuclear DNA content of the intraspecific somatic hybrids was lower than the expected DNA content. Valkonen et al. (1994) found a high correlation between $2 \mathrm{C}$ values and chromosome numbers in diploid, tetraploid and hexaploid Solanum species. The low $2 \mathrm{C}$ value of most of the somatic hybrids produced in the present experiment could be due to aneuploidy. One to three individual chromosomes may be missed in many regenerants. There were, however, also 
Rokka, V.-M. et al. Electrofusion of protoplasts of dihaploid lines of potato

some individual hybrids that had the expected or higher DNA content than the original cultivars. Also Rasmussen and Rasmussen (1995) noticed that hypoploidy was more general than hyperploidy among somatic hybrids. However, the association between the number of chromosomes and the phenotype of the plant is unclear. Lössl et al. (1994) have found no association, but Karp et al. (1989) have noticed that some aneuploids expressed phenotypic differences.

This paper reports successful production of somatic hybrids of anther-derived dihaploid po- tato lines. Further experiments are underway to characterize the disease resistance traits of the hybrids and to fuse new dihaploid lines having superior agronomic traits.

Acknowledgements. The authors wish to thank Ms. Leena Lohermaa and Ms. Kirsti Salmi for excellent technical assistance. Prof M. Umaerus, who kindly provided the dihaploid lines from The Swedish University of Agricultural Sciences, is also acknowledged. The authors want to thank Ann Fenwick M.S. for corrections in English language. This work was financially supported by the Finnish Ministry of Agriculture and Forestry.

\section{References}

Austin, S., Baer, M., Ehlenfeldt, M., Kazmierczak, P.J. \& Helgeson, J.P. 1985. Intra-specific fusions in Solanum tuberosum. Theoretical and Applied Genetics 71: 172175.

Baird, E., Cooper-Bland, S., Waugh, R., DeMaine, M. \& Powell, W. 1992. Molecular characterization of interand intra-specific somatic hybrids of potato using randomly amplified polymorphic DNA (RAPD) markers. Molecular and General Genetics 233: 469-475.

Binding, H., Bunning, D., Gorschen, E., Jorgensen, J., Kollmann, R., Krumbiegel- Schroeren, G., Ling, H.Q., Monzer, J., Mordhorst, G., Rudnick, J., Sauer, A., Witt, D. \& Zuba, M. 1988. Uniparental, fusant and chimaeric plants regenerated from protoplasts after streak plating in agarose gels. Plant Cell, Tissue and Organ Culture 12: 133-135.

Bokelmann, G.S. \& Roest, S. 1983. Plant regeneration from protoplasts of potato (Solanum tuberosum cv. Bintje). Zeitschrift für Pflanzenphysiologie 109: 259-265. Clulow, S.A., Wilkinson, M.J. \& Burch, R.L. 1993. Solanum phureja genes are expressed in the leaves and tubers of aneusomatic potato dihaploids. Euphytica 69: 16.

Cooper-Bland, S., DeMaine, M.J., Fleming, M.L.M.H., Phillips, M.S., Powell, W. \& Kumar, A. 1994. Synthesis of intraspecific somatic hybrids of Solanum tuberosum: assessments of morphological, biochemical and nematode (Globodera pallida) resistance characteristics. Journal of Experimental Botany 45: 1319-1325.

Creissen, G.P. \& Karp, A. 1985. Karyotypic changes in potato plants regenerated from protoplasts. Plant Cell, Tissue and Organ Culture 4: 171-182.

Debnath, S.C. \& Wenzel, G. 1987. Selection of somatic fusion products by hybrid vigour. Potato Research 30 : 371-380.

Dunwell, J.M. \& Sunderland, N. 1973. Anther culture of Solanum tuberosum L. Euphytica 22: 317-323.

Gleddie, S., Keller, W.A., \& Setterland, G. 1986. Pro- duction and characterization of somatic hybrids between Solanum melongena L. and S. sisymbriifolium Lam. Theoretical and Applied Genetics 71: 613-621.

Glimelius, K. 1988. Potentials of protoplast fusion in plant breeding programmes. Plant Cell, Tissue and Organ Culture 12: 163-172.

Hougas, R.W. \& Peloquin, S.J. 1957. A haploid plant of the potato variety Katahdin. Nature 180: 1202-1210.

Jones, H., Karp, A. \& Jones, M.G.K. 1989. Isolation, culture and regeneration of plants from potato protoplasts. Plant Cell Reports 8: 307-311.

Karp, A., Jones, M.G.K., Foulger, D., Fish, N. \& Bright, S.W.J. 1989. Variability in potato tissue culture. American Potato Journal 66: 669-684.

Lorenz, M., Weine, A. \& Börner,T. 1994. DNA fragments of organellar origin in random amplified polymorphic DNA (RAPD) patterns of sugar beet (Beta vulgaris L.). Theoretical and Applied Genetics 88: 775-779.

LössI, A., Frei, U. \& Wenzel, G. 1994. Interaction between cytoplasmic composition and yield parameters in somatic hybrids of $S$. tuberosum L. Theoretical and Applied Genetics 89: 873-878.

Masson, J., Lancelin, D., Bellini, C., Lecerf, M., Guerche, P. \& Pelletier, G. 1989. Selection of somatic hybrids between diploid clones of potato (Solanum tuberosum L.) transformed by direct gene transfer. Theoretical and Applied Genetics 78: 153-159.

Möllers, C., Frei, U. \& Wenzel, G. 1994. Field evaluation of tetraploid somatic potato hybrids. Theoretical and Applied Genetics 88: 147-152.

Möllers, C. \& Wenzel, G. 1992. Somatic hybridization of dihaploid potato protoplasts as a tool for potato breeding. Botanica Acta 105: 133-139.

Murashige, T. \& Skoog, F. 1962. A revised medium for rapid growth and bioassays with tobacco tissue cultures. Physiologia Plantarum 15: 473-497.

Pehu, E., Karp, A., Moore, K., Steele, S., Dunckley, R. \& Jones, M.G.K. 1989. Molecular, cytogenetic and mor- 


\section{AGRICULTURAL AND FOOD SCIENCE IN FINLAND}

Vol. 5 (1996): 449-460.

phological characterization of somatic hybrids of dihaploid Solanum tuberosum and diploid S. brevidens. Theoretical and Applied Genetics 78: 696-704.

- , Thomas, M., Poutala, T., Karp, A. \& Jones, M.G.K. 1990. Species-specific sequences in the genus Solanum: identification, characterization, and application to study somatic hybrids of $S$. brevidens and $S$. tuberosum. Theoretical and Applied Genetics 80: 693-698.

Puite, K.J., Ten Broeke, W. \& Schaart, J. 1988. Inhibition of cell wall synthesis improves flow cytometric sorting of potato heterofusions resulting in hybrid plants. Plant Science 56: 61-68.

Rasmussen, J.O. \& Rasmussen, O.S. 1995. Characterization of somatic hybrids of potato by use of RAPD markers and isozyme analysis. Physiologia Plantarum 93: 357-364.

Rokka, V.-M., Pietilä, L. \& Pehu, E. 1996. Enhanced production of dihaploid lines via anther culture of tetraploid potato (Solanum tuberosum L. ssp. tuberosum) clones. American Potato Journal 73: 1-12.

-, Valkonen, J.P.T. \& Pehu, E. 1995. Production and characterization of haploids derived from somatic hybrids between Solanum brevidens and $S$. tuberosum through anther culture. Plant Science 112: 85-95.

- , Xu, Y-S., Kankila, J., Kuusela, A., Pulli, S. \& Pehu, E. 1994. Identification of somatic hybrids of dihaploid Solanum tuberosum lines and $S$. brevidens by species specific RAPD patterns and assessment of disease resistance of the hybrids. Euphytica 80: 207-217.

Ross, H. 1986. Potato breeding - problems and perspectives. Paul Parey Verlag, Berlin. 132 p.

Schweis, A. \& Munzert, M. 1993. First experience with the application of protoplast fusion in practical potato breeding. EAPR 93, 12th Triennal Conference of European Association for Potato Research. INRA, Paris. p. 103-104.

Tempelaar, M.J. \& Jones, M.G.K. 1985. Directed electrofusion with different responses in a mass fusion sys- tem. Plant Cell Reports 4: 42-45.

Tiainen, T.K. 1992. The role of ethylene and reducing agents on anther culture response of tetraploid potato (Solanum tuberosum L.). Plant Cell Reports 10: 604-607. Valkonen, J.P.T., Watanabe, K.N. \& Pehu, E. 1994. Analysis of correlation between nuclear DNA content, chromosome number, and flowering capacity of asymmetric somatic hybrids of diploid Solanum brevidens and (di)haploid S. tuberosum. Japanese Journal of Genetics 69: 525-536.

Waara, S., Pijnacker, M.A., Ferwerda, M.A., Wallin, A. \& Eriksson, T. 1992. A cytogenetic and phenotypic characterization of somatic hybrid plants obtained after fusion of two different dihaploid clones of potato (Solanum tuberosum L.) Theoretical and Applied Genetics 85: 470479.

- , Tegelström, H., Wallin, A. \& Eriksson, T. 1989. Somatic hybridization between anther-derived dihaploid clones of potato (Solanum tuberosum L.) and the identification of hybrid plants by isozyme analysis. Theoretical and Applied Genetics 77: 49-56.

- , Wallin, A. \& Eriksson, T. 1991. Production and analysis of intraspecific somatic hybrids of potato (Solanum tuberosum L.). Plant Science 75: 107-115.

Wenzel, G., Schieder, O., Przewozny, T., Sopory, S.K., \& Melchers, G. 1979. Comparison of single cell culture derived Solanum tuberosum L. plants and a model for their application in breeding programs. Theoretical and Applied Genetics 55: 49-55.

White, D.R.W. \& Vasil, I.K. 1979. Use of amino acid analogue-resistant cell lines for selection of Nicotiana sylvestris somatic cell hybrids. Theoretical and Applied Genetics 55: 107-112.

Xu, Y-S., Jones, M.G.K., Karp, A. \& Pehu, E. 1993. Analysis of the mitochondrial DNA of the somatic hybrids of Solanum brevidens and Solanum tuberosum using nonradioactive digoxigenin-labelled DNA probes. Theoretical and Applied Genetics 85: 1017-1022. 


\title{
AGRICULTURAL AND FOOD SCIENCE IN FINLAND
}

Rokka, V.-M. et al. Electrofusion of protoplasts of dihaploid lines of potato

\section{SELOSTUS}

\section{Perunalajikkeiden ponsiviljelyllä tuotettujen dihapioidien protoplastien sähköfuusio}

\author{
Veli-Matti Rokka, Yong-Sheng Xu, Pirjo Tanhuanpää, Leena Pietilä ja Eija Pehu \\ Maatalouden tutkimuskeskus, Helsingin yliopisto ja Boreal Suomen Kasvinjalostus
}

\begin{abstract}
Protoplasteilla tarkoitetaan soluja, joiden solunseinä on poistettu entsymaattisesti. Tällaisia soluja voidaan fuusioida yhteen, jolloin kahden eri perunalinjan yhdistelmästä muodostuu solujen kasvatuksen jälkeen somaattisia hybridejä. Somaattiset hybridit ovat perunan jalostukselle tärkeitä, koska tavanomainen jalostus, joka tapahtuu tetraploidien $(4 \mathrm{x})$ kasvien suvullisin risteytyksin, tarvitsee runsaasti risteytyksiä ja suuren määrän jälkeläisiä. Käyttämällä hyväksi dihaploideja $(2 \mathrm{x})$ perunoita ja fuusioimalla linjoja $\mathrm{yh}$ teen $(2 x+2 x)$, voidaan perunan jalostusta sekä nopeuttaa että tehostaa.

Tässä työssä ponsiviljelyllä tuotetuista dihaploideista perunalinjoista (peräisin lajikkeista Matilda, Nicola, Pito, Stina, Van Gogh ja White Lady) eristettiin protoplasteja, joita fuusioitiin sähköisesti. Kahden eri dihaploidin protoplasteja fuusioimalla saatiin tuotettua somaattisia hybridejä. Saadut kuusi uutta
\end{abstract}

fuusioyhdistelmää analysoitiin käyttämällä RAPDmerkkejä. Oletetut hybridit määritettiin useimmiten kahdella alukkeella, jotka kumpikin tuottivat dihaploideille vanhempaislinjoille spesifisen merkin.

Useimmat tuotetut somaattiset hybridit olivat tetraploideja $(4 \mathrm{x})$, mutta neljästä fuusioidusta yhdistelmästä muodostui myös kasveja, joilla oli joko heksaploidinen (6x), oktoploidinen (8x) tai miksoploidinen genomi. Tämä tutkittiin laskemalla hybridien kromosomit tai analysoimalla kasvit virtaussytometrillä. Somaattisten hybridien DNA-pitoisuuksien oletettiin olevan yhtä suuria kuin tetraploidien perunoiden DNA-pitoisuudet tai dihaploidien fuusiovanhempien DNA-pitoisuuksien summat. Kuitenkin useiden tetra- ja heksaploidien hybridien DNA-pitoisuuksien keskiarvot olivat pienempiä kuin oletetut DNA-pitoisuudet. 